\title{
PREVALENCE OF THE GIANT LIVER FLUKE (Fascioloides magna, Bassi, 1875) IN RED DEER (Cervus elaphus) IN THE REGION OF FLOODPLAIN FORESTS OF NORTHERN SERBIA.
}

\author{
Jovan Mirčeta ${ }^{1 *}$, Miloš Pelić́ ${ }^{1}$, Biljana Božić ${ }^{2}$, Jelena Petrović ${ }^{2}$, \\ Miroslav Uroševićc ${ }^{3}$, Branislav Stankov ${ }^{1}$, Dejan Bugarski ${ }^{2}$ \\ ${ }^{1} \mathrm{JP}^{\prime}$ "Vojvodinašume“, Petrovaradin, Serbia \\ ${ }^{2}$ Scientific Veterinary Institute "Novi Sad", Serbia \\ ${ }^{3}$ Institute for reproduction and artificial insemination, Temerin, Serbia
}

\section{Abstract}

This is the first study offering insights into the prevalence of giant liver fluke in the population of red deer in the territory of Serbia. Giang liver fluke (Fascioloides magna, Bassi, 1875) is the most important liver parasite among wild ruminants in Europe, especially in the region of floodplain forests along the upper watercourse of Danube river. The main objective of this research was establishing the prevalence of giant liver fluke in the region of floodplain forests of northern Serbia. In the observed regions (hunting grounds), the population prevalence rates ranged from 0 to $80 \%$ with an average prevalence in positive herds being $70.6 \%$. The total population of red deer, from the observed hunting grounds, exposed to the giant liver fluke includes $47.9 \%$ of red deer population in Serbia, which is $0.7 \%$ of the total hunting area of Serbia. Giant liver fluke is present in north-western regions of Serbia in a narrow area of floodplain forests along the watercourse of Danube and Sava rivers next to the border with Croatia. The red deers populating the wetland basin of "Gornje Podunavlje" migrate freely through the tri-border area of Hungary, Croatia and Serbia making a consistent epizootical unit. Moreover, the game migrates freely between Croatia and Serbia in the area of Posavina forests along the river Sava. All data obtained in this research are essential for further activities aimed at preventing the spread of this parasite within red deer population and thus decreasing consequent damages and losses.

Keywords: giant liver fluke, red deer, prevalence, Danube, Sava

${ }^{1 *}$ Corresponding author: mircetajovan@gmail.com 


\title{
PREVALENCIJA AMERIČKOG METILJA (Fascioloides magna, Bassi, 1875) KOD EVROPSKOG JELENA (Cervus elaphus) NA PODRUČJU PLAVNIH ŠUMA SEVERNE SRBIJE.
}

\author{
Jovan Mirčeta ${ }^{1^{*}}$, Miloš Pelić ${ }^{2}$, Biljana Božić ${ }^{2}$, Jelena Petrović2, \\ Miroslav Uroševićc ${ }^{3}$, Branislav Stankov ${ }^{1}$, Dejan Bugarski ${ }^{2}$ \\ ${ }^{1}$ JP"Vojvodinašume“, Petrovaradin, Srbija \\ ${ }^{2}$ Naučni institut za veterinarstvo „Novi Sad“, Novi Sad, Srbija \\ ${ }^{3}$ Naučni institu za reprodukciju i veštačko osemenjavanje, Temerin, Srbija
}

\section{Kratak sadržaj}

Ovo je prvi rad koji pruža uvid u prevalenciju prisustva američkog metilja u populaciji evropskog jelena na prostoru Srbije. Američki metilj (Fascioloides magna, Bassi, 1875) je najznačajni parazit jetre divljih preživara Evrope, a pogotovo na području podunavskih plavnih šuma $u$ gornjem toku. Ovaj rad je imao za cilj da utvrdi prevalenciju američkog metilja kod evropskog jelena (Cervus elaphus) na području plavnih šuma severne Srbije. Prevalencija u posmatranim regionima (lovištima), u populacijama evropskog jelena se kretala od 0-80\%, sa prosečnom prevalencijom kod pozitivnih populacija od 70,6\%. Ukupna populacija evropskog jelena, poreklom iz posmatranih lovišta, izložena američkom metilju je 47,9\% ukupne populacije evropskog jelena na teritoriji Srbije, koja se nalazi na 0,7\% ukupne lovne površine Srbije. Američki metilj je prisutan u severozapadnim delu Srbije, u uskom pojasu podunavskih i posavskih plavnih šuma, uz granicu sa Hrvatskom. Jeleni koji obitavaju u basenu plavnih šuma "Gornje Podunavlje" slobodno migriraju u trouglu Mađarska, Hrvatska i Srbija i čine jedinstvenu epizootiološku celinu, takođe kao i na području posavskih šuma jeleni se slobodno kreću u pograničnom pojasu Hrvatske i Srbije. Svi dobijeni podaci su neophodni za buduće aktivnosti u cilju prevencije širenja i smanjivanja šteta u populaciji evropskog jelena.

Ključne reči: američki metilj, evropski jelen, prevalencija, Dunav, Sava 


\section{INTRODUCTION}

Giant liver fluke (Fascioloides magna, Bassi, 1875) is nowadays considered the most important liver parasite in wild ruminants in Europe, especially in the regions along the watercourse of Danube river (Králová-Hromadová et al., 2016). Giant liver fluke is a parasitic organism of the class Trematoda family Fasciolidaese. Mature fluke usually measures $4-10 \mathrm{~cm}$ in length, $2-3.5 \mathrm{~cm}$ in width and are $0.2-0.45 \mathrm{~cm}$ thick (Figure 1.) (Erhardová, 1961). The organism is highly invasive species, which is mainly due to the wide spectrum of potential definitive and intermediate hosts, its pronounced ability to adapt to new hosts, extensive spatial distribution and potential to colonize new territories (Králová-Hromadová et al., 2016; Pybus, 2001).

The development and life cycle of giant liver fluke requires an aquatic snail (Lymnaea spp., Radix spp.) as an intermediate host (Erhardová-Kotrlá, 1971; Pybus, 2001). The development in the interemediate host lasts some 2.5 months, while the metacercariae remain infectious for the host during $2-2.5$ months (Králová-Hromadová et al., 2016; Pybus 2001). In case of Fascioloides magna, further development is determined by host species, which are divided into definitive, dead-end and aberrant ones (Pybus, 2001). Upon ingestion of infectious metacercariae, the prepatent period in definitive hosts can extend from 3 (Erhardová-Kotrlá, 1971) to even 7 months (Foreyt and Todd, 1976). In Europe, red deer (Cervus elaphus) and fallow deer (Dama dama) are the most common definitive hosts that facilitate completing of the life cycle of Fascioloides magna in liver pseudocyst and release of eggs via the billiary liver system into the intestines (Králová-Hromadová et al., 2016; Pybus, 2001). Adult flukes can survive in definitive hosts even up to five years (Erhardová-Kotrlá, 1971).
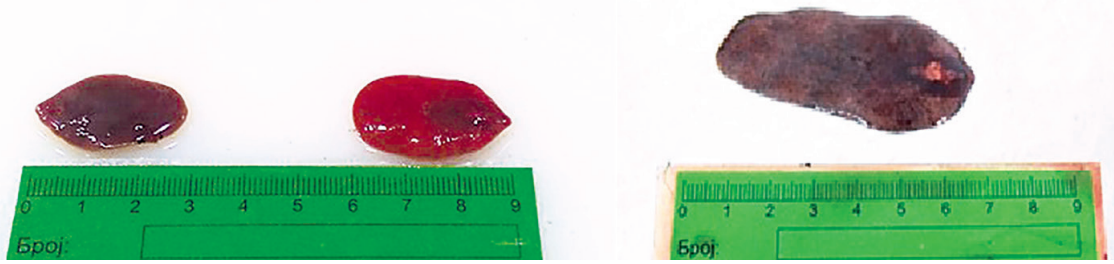

Figure 1. Giant liver fluke (Fascioloides magna, Bassi, 1875).

The parasite is originally native to North America, but has been introduced to Europe during import of North American deers. The first case recorded in Europe was in the wapiti stag (Cervus elaphus nelsoni) imported in 1865 from 
Wyoming (USA) into the Royal National Park La Mandria in northwestern Italy (Pybus, 2001). Besides the territory of Italy, two further infection foci were identified in the region of Czech-Polish border and floodplain forests along the Danube in Central Europe (Králová-Hromadová et al., 2011, 2016). The first reports on substantial spread of giant liver fluke in Danube River Basin have been published during last 25 years, confirming its presence in Slovakia (Rajský et al., 1994), Hungary (Majoros and Sztojkov, 1994), Austria (Winkelmayer and Prosl, 2001), East Croatia (Marinculić et al., 2002) and northwestern parts of Serbia (Trailović et al., 2008).

The most common pathoanatomical finding in the liver associated with giant liver fluke infection includes presence of fibrous pseudocysts containing usually two parasites (pairs), free migrating of immature flukes, marbled black pigmentation (hematin) of the parenchyma or below the capsule, rupture of the capsule and perihepatitis (Pybus, 2001). Giant liver fluke infection in definitive host usually results in poor growth, decreased productivity and (rarely) mortality (Pybus et al., 2015; Trailović et al., 2008).

Only two members of the family Fasciolidae, Fasciola hepatica and Fasciola gigantica, manifest zoonotic potential, while human infections associated with Fascioloides magna have not been reported so far (Mas-Coma, 2005; Pybus, 2001). Hygienic safety of meat and internal organs is evaluated using the same method as in the case of domestic ungulate fascioliasis, depending on the invasion rate and apparent changes (Herenda et al., 2000).

The objective of this research was to establish the prevalence of giant liver fluke (Fascioloides magna, Bassi, 1875) in the region of floodplain forests of northern Serbia. The data obtained in this research are indispensible for further activities aimed at preventing the spread of this parasite within red deer population and thus decreasing consequent damages and losses.

\section{MATERIAL AND METHODS}

The research was conducted in the period September 2017 - January 2018 in the territory of northern Serbia (Vojvodina region) encompassing total 3.275 ha in the provinces of Bačka, Srem and Banat. In the province of Bačka, we observed the hunting areas: "Kozara", "Apatinski rit" and "Plavna", in the province of Srem "Bosutske šume", "Kućine" and "Karakuša", and in the province of Banat hunting ground "Deliblatska peščara" (Table 1.). The investigation sites are located along the watercourse of Danube and Sava rivers, mostly in floodplain forest habitats containing most dense red deer population. Observed red deer are grouped into three separate populations (Bačka, Srem, and 
Banat) based on territorial (regional) separation or degree of mutual contact (Figure 2.).

Table 1. Investigated hunting grounds, surface area and density of red deer (Cervus elaphus) population.

\begin{tabular}{|c|c|c|c|c|c|c|}
\hline Region & District & $\begin{array}{l}\text { Munici- } \\
\text { pality }\end{array}$ & $\begin{array}{c}\text { Hunting } \\
\text { ground (ID } \\
\text { number) }\end{array}$ & $\begin{array}{l}\text { Number } \\
\text { of individ. } \\
\text { animals }\end{array}$ & $\begin{array}{c}\text { Surface } \\
\text { area of the } \\
\text { hunting } \\
\text { ground (ha) }\end{array}$ & $\begin{array}{c}\text { Population } \\
\text { density } \\
\text { (number } \\
\text { of animals } \\
\text { / 100 ha) }\end{array}$ \\
\hline \multirow{4}{*}{ Bačka } & \multirow{2}{*}{ West Bačka } & Sombor & $\begin{array}{c}\text { "Kozara" } \\
(2332)\end{array}$ & 1.426 & $11.507,63$ & 12,39 \\
\hline & & Apatin & $\begin{array}{l}\text { "Apatinski } \\
\text { rit“ (2331) }\end{array}$ & 411 & $6.335,76$ & 6,49 \\
\hline & $\begin{array}{l}\text { South } \\
\text { Bačka }\end{array}$ & Bač & \begin{tabular}{|c|} 
"Plavna“ \\
(2334)
\end{tabular} & 118 & $3.629,29$ & 3,25 \\
\hline & \multicolumn{3}{|c|}{$\Sigma$} & 1.955 & 21.472 & 9,10 \\
\hline \multirow{4}{*}{ Srem } & \multirow{3}{*}{ Srem } & \multirow[t]{2}{*}{ Šid } & $\begin{array}{l}\text { "Bosutske } \\
\text { šume“" } \\
(3015)\end{array}$ & 402 & $14.912,18$ & 2,70 \\
\hline & & & $\begin{array}{c}\text { "Kućine“ } \\
(3018)\end{array}$ & 89 & $1.986,48$ & 4,48 \\
\hline & & Ruma & \begin{tabular}{|c} 
"Karakuša“ \\
$(3016)$
\end{tabular} & 165 & $8.125,22$ & 2,03 \\
\hline & \multicolumn{3}{|c|}{$\Sigma$} & 656 & 25.023 & 2,62 \\
\hline \multirow[t]{2}{*}{ Banat } & $\begin{array}{l}\text { South } \\
\text { Banat }\end{array}$ & Kovin & $\begin{array}{c}\text { „Deliblats- } \\
\text { ka peščara“ } \\
(2710)\end{array}$ & 664 & 31.036 & 2,14 \\
\hline & \multicolumn{3}{|r|}{ 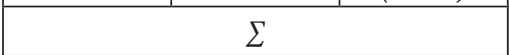 } & 664 & 31.036 & 2,14 \\
\hline \multicolumn{4}{|c|}{ Bačka+Srem } & 2.611 & 46.495 & 5,62 \\
\hline \multicolumn{4}{|c|}{ Bačka+Srem+Banat } & 3.275 & 77.531 & 4,22 \\
\hline
\end{tabular}

The total area encompassed by the sampling was 60.396 ha with an estimated population of 3.275 deer game animals. A total of 79 samples of red deer liver was examined for the presence of the giant liver fluke (Fascioloides magna, Bassi, 1875). All animals encompassed by this research were shot during regular hunting. After shooting, the livers were collected, labeled and individually packet into the plastic bags and stored at $4^{\circ} \mathrm{C}$. Subsequently, parasitological and pathomorphological examination were performed. Parasitological and pathomorphological examination revealed the presence of parasites and the 
invasion rate and pathoanatomical liver changes were recorded. The obtained data were statistically analyzed using IBM SPSS Statistics 20 (IBM, Armonk, NY, USA), and for figure graphic processing we used software desktop QGIS 3.2.1 (OSGeo, USA) and CRS MGI 1901/Balkans zone 7, EPSG:3909.

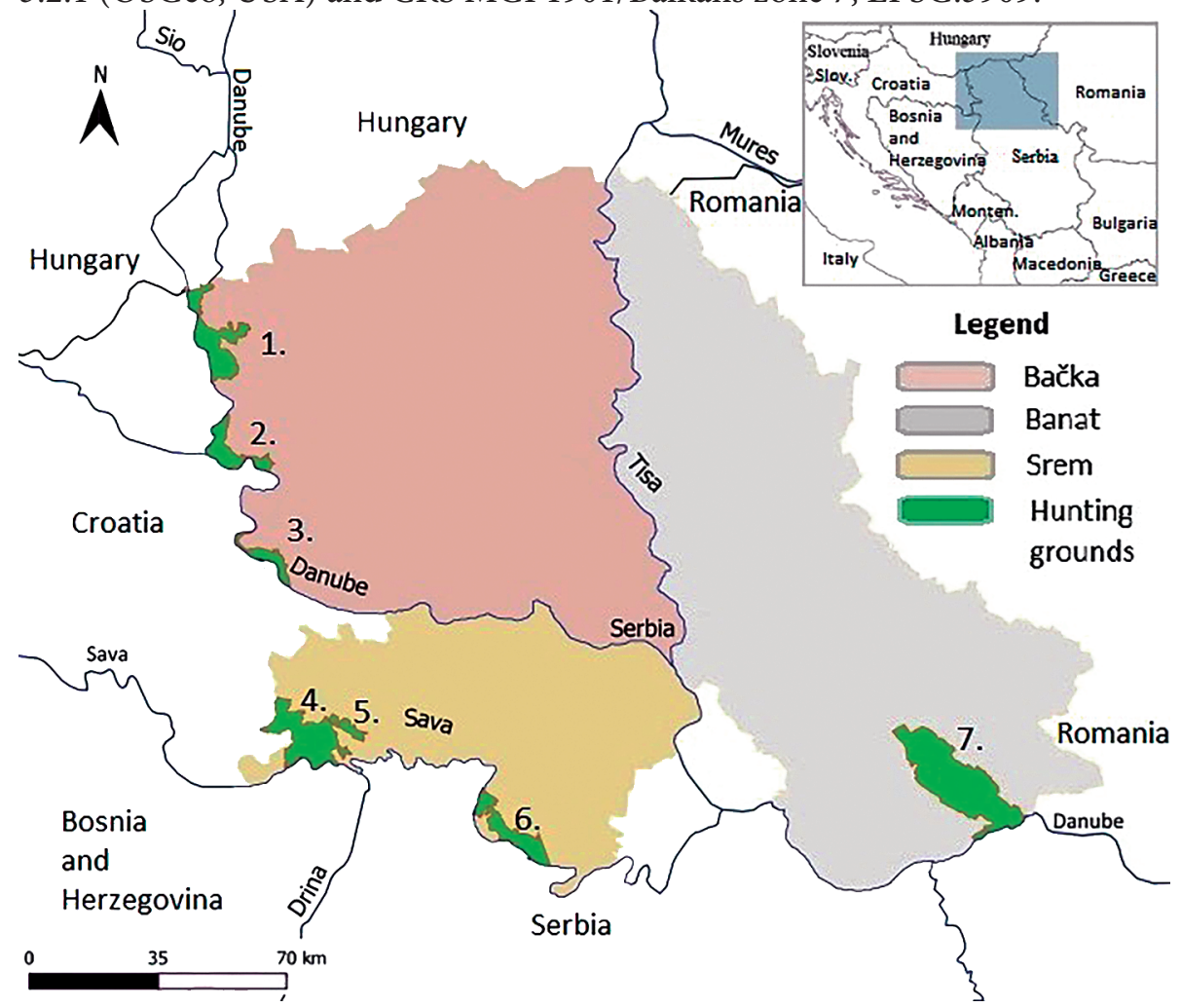

Figure 2. Location of the hunting ground (1. „Kozara“, 2. „Apatinski rit“, 3. „ Plavna“, 4. „Bosutske šume“, 5. „Kućine“, 6. „Karakuša“, i 7. „Deliblatska peščara“).

\section{RESULTS}

Total number of 79 livers from three distinct red deer populations was investigated as following: 25 livers from the hunting grounds in Bačka region, 26 livers from hunting grounds in Srem region and 28 livers from the hunting grounds in the Banat region revealing the overall prevalence of $45.6 \%(36 / 79)$ of positive animals. Among the red deer population on observed hunting grounds in the region of Bačka, the presence of parasite was confirmed in $80 \%$ $(20 / 25)$ animals out of which $35 \%$ had $10 \geq$ parasites in the liver, whereas the findings from hunting grounds in the region of Srem revealed parasite pres- 
ence in $61.5 \%(16 / 26)$ animals and $75 \%$ with $10 \geq$ parasites in the liver. An average prevalence in populations with confirmed presence of giant liver fluke was $70.6 \%(36 / 51)$ animals, out of which $52.8 \%$ contained $10 \geq$ parasites in the liver. On the observed hunting ground in the territory of Banat, the presence of giant liver fluke has not been confirmed in the population of red deer. All animals positive for the presence of giant liver fluke originated from floodplain forests along the upper watercourse of Danube and Sava rivers in Serbia.

Table 2. The prevalence of giant liver fluke within red deer population and liver invasion rate.

\begin{tabular}{|c|c|c|c|c|c|}
\hline \multirow{2}{*}{ Region } & \multirow{2}{*}{$\begin{array}{c}\text { Number of } \\
\text { samples }\end{array}$} & \multirow{2}{*}{ Prevalence } & \multicolumn{3}{|c|}{ Invasion rate } \\
\cline { 4 - 6 } & 25 & $20(80)$ & $7(35)$ & $4(20)$ & $9(45)$ \\
& 26 & $16(61.5)$ & $12(75)$ & $3(18.8)$ & $1(6.2)$ \\
\hline Bačka & 28 & 0 & 0 & 0 & 0 \\
\hline Srem & 79 & $36(4.6)$ & $19(52.8)$ & $7(19.4)$ & $10(27.8)$ \\
\hline Banat & Total & & & $\begin{array}{c}\text { Medium } \\
(3-9)\end{array}$ & Low $(\leq 2)$ \\
\hline
\end{tabular}

Giant liver fluke was identified in 36 livers. The observed pathoanatomical changes revealed presence of cysts filled with dark-coloured substance containing parasites, which in case of large number of individuals protrude above the liver surface and alter its outer appearance (Figure 3.). Liver parenchyma was marbled with dark pigmented stripes and spots in $63.9 \%$ (23/36) of cases, whereas perihepatitis was observed in 69.4\% (25/36) livers.

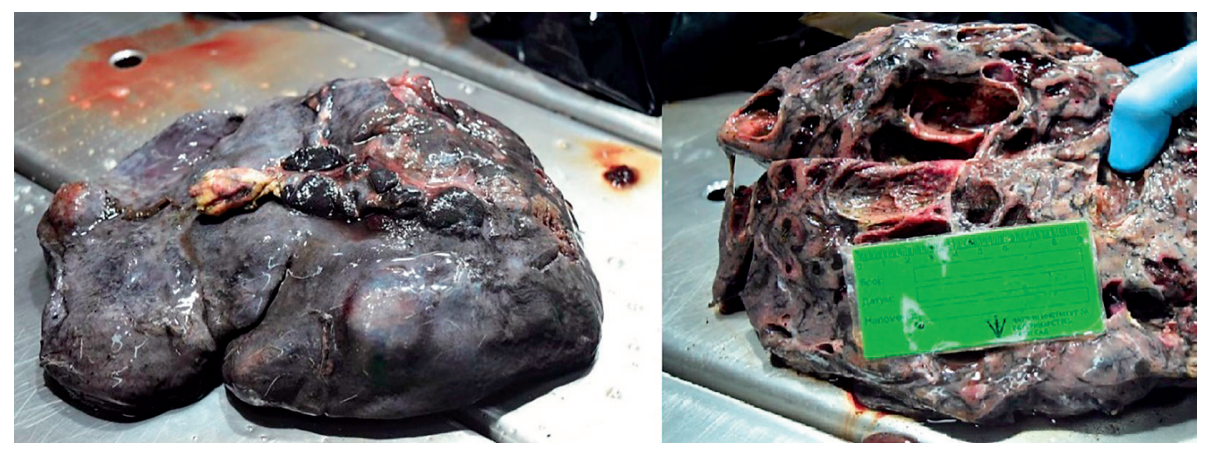

Figure 3. The presence of pseudocysts in the liver of red deer associated with giant liver fluke (Fascioloides magna, Bassi, 1875) infection. 


\section{DISCUSSION}

First reports on the presence of giant liver fluke in Serbia date back to 2008. The parasite was indentified in fallow deer (Dama dama) originated from fenced hunting ground in South- Bačka District (Trailović et al., 2008, 2016). The data on the presence and/or distribution of giant liver fluke infection in red deer (Cervus elaphus) have not been available so far. Some available literature data on the presence of giant liver fluke among the red deer populations in neighboring countries such as Hungary and Croatia (Majoros and Sztojkov, 1994; Pybus, 2001; Marinculić et al., 2002; Janicki et al., 2005) suggested potential presence of the parasite in Serbia, especially in northwestern regions bordering Hungary and Croatia. In countries of the Danube River Basin, the programs for monitoring giant liver fluke in deer game have been implemented and are mainly based on the identification of parasites and/or their eggs in the faeces.

The prevalence of giant liver fluke recored in the observed population of red deer in the area of floodplain forests of northern Serbia ranged from 0 to $80.0 \%$ with an average prevalence in positive herds being $70.6 \%(61.5-80.0 \%)$, which corresponds with the results in the countries of the Danube River Basin such as Slovakia, Austria, Hungary and Croatia, where prevalence rates sometimes exceeded 60\% (Rajský et al., 2002; Špakulová et al., 1997; Giczi, 2008; Králová-Hromadová et al., 2016; Slavica et al., 2006). The invasion rate in positive livers ranged 6.3 - $45 \%$ for low invasion rate ( $\leq 2$ parasites), $18.8-20 \%$ for medium invasion rate (3-9 parasites), and $35-75 \%$ for high invasion rate ( $10 \geq$ parasites) (Table 2.).

The dominant population of large game in the northern part of Serbia includes roe deer (Capreolus capreolus), wild boar (Sus scrofa) and red deer (Cervus elaphus). In the territory of Serbia, hunting grounds occupy 7.132.368 ha, out of which 1.964.957 ha are in Vojvodina Region (Statistical bulletin, 2016). The population of red deer in Serbia is estimated to 5.522 animals, out of which 4.337 animals are in Vojvodina Region (Statistical bulletin, 2016). In this research, we identified and defined the area in which the presence of giant liver fluke has been confirmed, that is, 46,495 ha of the total 60,396 ha that makes $0.7 \%$ and $2.4 \%$ of the total hunting ground surface in Serbia and Vojvodina, respectively, and with an average density of the investigated population being 5.6 animals / 100 ha. Total population exposed to the giant liver fluke infection includes 2,611 animals from observed hunting area of 46,495 ha, which makes $47.9 \%$ and $60.2 \%$ of red deer population in Serbia and Vojvodina Region, respectively. 


\section{CONCLUSION}

The data on the prevalence of giant liver fluke within the observed hunting grounds in the area of floodplain forests of northern Serbia, provides important insights into the high rate of exposure and hazards to the population of red deer. Moreover, the broad transboundary epizootical area strongly suggest the necessity of continuous monitoring of distribution of giant liver fluke with an aim of preventing its spreading and preventing the damages and losses in the population of red deer in this area.

\section{ACKNOWLEDGEMENTS}

The presented work is part of the research done in researh project number TR31084 granted by the Serbian Ministry of Education, Science and Technological Development.

\section{REFERENCES}

1. Erhardová B.: Fascioloides magna in Europe. Helminthologia, 1961, 3, 91-106.

2. Erhardová-Kotrlá B.: The occurence of Fascioloides magna (Bassi, 1875) in Czechoslovakia. Prague: Academia; 1971.

3. Foreyt W.J., Todd A.C. :The development of the large American liver fluke, Fascioloides magna, in white-tailed deer, cattle, and sheep. Journal of Parasitology, 62, 26-32, 1976.

4. Giczi E.: Fascioloides magna (Bassi, 1875) infection of Hungarian red deer and roe deer stock and the possibility of protection. Dissertation, University of West Hungary, 2008.

5. Herenda D.: Manual on Meat Inspection for Developing Countries, Food and Agriculture Organization of the United Nations, 2000. Accessed February 19, 2018. http://www.fao.org/docrep/003/t0756e/t0756e00.HTM.

6. Janicki Z., Konjević D., Severin K.: Monitoring and treatment of Fascioloides magna in semi-farm red deer husbandry in Croatia. Veterinary Research Communications, 29, 83-88, 2005.

7. Králová-Hromadová I., Bazsalovicsová E., Štefka J., Špakulová M., Vávrová S., Szemes T., Tkach V., Trudgett A., Pybus M.: Multiple origins of European populations of the giant liver fluke Fascioloides magna (Trematoda: Fasciolidae), a liver parasite of ruminants. International Journal for Parasitology, 41, 373-383, 2011.

8. Králová-Hromadová I., Juhásová L., Bazsalovicsová E.: The Giant Liver Fluke, Fascioloides magna: Past, present and future research. Heidelberg, Germany, Springer International Publishing, 2016. 
9. Majoros G., Sztojkov V.: Appearance of the large American liver fluke Fascioloides magna (Bassi, 1875) (Trematoda: Fasciolata) in Hungary. Parasitologia Hungarica, 27, 27-38, 1994.

10. Marinculić A., Džakula N., Janicki Z., Hardy Z., Lučinger S., Živičnjak T.: Appearance of American liver fluke (Fascioloides magna, Bassi, 1875) in Croatia - A case report. Veterinarski Arhiv, 72, 319-325, 2002.

11. Mas-Coma S.: Epidemiology of fascioliasis in human endemic areas. Journal of Helminthology, 79:207-216, 2005.

12. Pybus M.J.: Liver flukes. In: Samuel WM, Pybus MJ, Kocan AA (eds) Parasitic diseases of wild mammals, 2nd edn. Iowa State University Press, Ames, 2001.

13. Pybus M.J., Butterworth E.W., Woods J.G.: An expanding population of the giant liver fluke (Fascioloides magna) in elk (Cervus canadensis) and other ungulates in Canada. Journal of Wildlife Diseases, 51, 431-45, 2015.

14. Rajský D., Patus A., Bukovjan K.: Prvý nález Fascioloides magna Bassi, 1875 na Slovensku. Slovenský veterinársky časopis, 19, 29-30, 1994.

15. Rajský D., Čorba J., Várady M., Špakulová M., Cabadaj R.: Control of fascioloidosis (Fascioloides magna Bassi, 1875) in red deer and roe deer. Helminthologia, 39, 67-70, 2002.

16. Republički zavod za statistiku (RZS) Srbije, Statistički bilten: Šumarstvo u Republici Srbiji, Beograd, Republika Srbija - Republički zavod za statistiku, 2016.

17. Slavica A., Florijančić T., Janicki Z., Konjević D., Severin K., Marinculić A., Pintur K.: Treatment of fascioloidosis (Fascioloides magna, Bassi 1875) in free ranging and captive red deer (Cervus elaphus L.) at eastern Croatia. Veterinarski arhiv, 76, 9-18, 2006.

18. Špakulová M., Čorba J., Varády M., Rajský D.: Bionomy, distribution and importance of giant liver fluke (Fascioloides magna), an important parasite of free-living ruminants. Veterinární medicína, 42, 5, 139-148, 1997.

19. Trailović S., Kulišić Z., Marinković D.: Fascioloides magna in deer population in Vojvodina - our expiriences. In XXIX Veterinary innovations. Belgrade, Serbia; 2008, 29-40.

20. Trailović S., Marinković D., Kulišić Z.: Diagnosis and therapy of liver fluke (Fascioloides magna) infection in fallow deer (Dama dama) in Serbia. Journal of Wildlife Diseases, 52, 2, 319-326, 2016.

21. Winkelmayer R., Prosl H.: Riesenleberegel-jetzt auch bei uns?, Österreichisches Weidwerk, 3, 42-44, 2001. 